\title{
The Discourse on Humour in the Romanian Press between 1948-1965
}

EUGEN CONSTANTIN IGNAT

University of Bucharest

\section{INTRODUCTION}

Once the official proclamation of the Romanian People's Republic takes place, on the $30^{\text {th }}$ of December 1947, the process of imposing new cultural values on society gradually permeates all areas of Romanian social life. Humour also becomes part of this process of transforming the social and cultural life, often regarded as a powerful weapon with which to attack 'old' bourgeois mentalities. According to Hans Speier, the official type of humour promoted by an authoritarian regime is political humour, which contributes to maintain the existent social order, or plays its part in changing it - all depending on those holding the reins over massmedia. ${ }^{1}$ Taking the Soviet Union as a model, the Romanian new regime imposes an official kind of humour, created through mass-media: the press, the radio, literature, cinematography, and television. This paper analyses the Romanian discourse on humour, reflected in the press, between 1948-1965, ${ }^{2}$ in cultural magazines ${ }^{3}$ such as Contemporanul (1948-1965), Probleme de

\footnotetext{
${ }^{1}$ Hans Speier, 'Wit and politics. An essay on laughter and power,' American Journal of Sociology, 103 (1998), p.1353.

2 This period represents the first phase in the history of the communist regime in Romania. After a transitional period (1944-1947), the year 1948 marks the establishment of the communist regime in Romania. Through a series of political, economic, social, and cultural measures, such as the adoption of a new Constitution, banning of opposition parties, nationalization of the means of production, radical transformation of the education system or 'Sovietisation' of culture, the new regime radically transforms Romanian society. Until 1965, the leader of the Romanian communist regime is Gheorghe Gheorghiu-Dej. See Ghiță Ionescu, Communism in Rumania (Oxford University Press, London, 1964), Dennis Deletant, Romania under the communist rule (The Center for Romanian Studies, Oxford, 1999).

${ }^{3}$ Whereas Contemporanul was a cultural magazine with a general perspective, Probleme de cinematografie, Film and Cinema were film magazines.
} 
Ignat - The Discourse on Humour In the Romanian Press Between 1948-1965

cinematografie (1951-1955), Film (1956-1958), and Cinema (1963-1965). One of the most popular forms of humour in socialist Romania was film comedy. For this reason, this article focuses especially on the discourse on humour regarding film comedy. ${ }^{4} \mathrm{My}$ thesis is that the emergence of socialist comedy films in the mid-1950s has a strong impact on the discourse on humour as reflected in the press.

Humour appears in many forms, including comedy, satire, burlesque, derision, farce, joke, irony, mockery, parody, puns, ridicule, sarcasm, slapstick, or witticism. Sometimes it is positive, other times it can be negative. It can be playful or serious. It can be repressive or subversive. My analysis of the official discourse on humour in this period distinguishes between three different phases, each proposing a distinct type of humour: the period between 1948-1953, emphasizing satirical comedy as a way of criticizing and fighting against negative phenomena in society $;^{5}$ the period between 1953-1955, which I argue is a transitional period, during which the official discourse seems to abandon the stress upon satirical comedy and moves towards one which emphasizes the need to create both stronger positive characters, as well as comical works which portray the new society in an optimistic fashion; and lastly, the period between 1956-1965, whose use of humour blends together optimistic comedy, centred on positive characters typical of the new society, with a benevolent ${ }^{6}$ kind of satire.

\section{Humour TheOries: A BRIEF OvERVIEW}

Humour is an essential feature of human life and the study of humour has been a concern for scholars since Antiquity. ${ }^{7}$ Modern research on humour begins with the works published on this subject by the French philosopher Henri Bergson ${ }^{8}$ and the founder of psychoanalysis,

${ }^{4}$ With the advent of comedy films in the mid-1950s there is a growing concern about the humour in the press.

${ }^{5}$ By ridiculing attitudes viewed as remainders of the old regime.

6 The term benevolent humour was introduced by Anatoli Lunacharsky in 1920s in the Soviet Union in order to make a distinction between the humour aimed at the pillar of the old order (cruel humour) and the humour whose aim was to criticize the new socialist order in a friendly manner. See Richard Taylor, 'A "Cinema for the Millions": Soviet Socialist Realism and the Problem of Film Comedy,' Journal of Contemporary History 18.3 (1983), pp. 454-455.

7 Richard Janko, Aristotle on Comedy. Towards a reconstruction of Poetics II (University of California Press, Los Angeles, 1984).

${ }^{8}$ Henri Bergson, Le rire. Essai sur la signification du comique [Laughter. An Essay on the meaning of the Comic] (Presse Universitaire de France, Paris, 1900).

(C) School of Slavonic and Eastern European Studies, University College London, 2018. 
Ignat - The Discourse on Humour In the Romanian Press Between 1948-1965

Sigmund Freud. ${ }^{9}$ The importance of these works, both for later research and for the present work, comes from the fact that they have highlighted the social character of humour. ${ }^{10}$ Starting from this context, studies of humour have developed and multiplied in social sciences throughout the twentieth century, so we can now discuss several approaches to the phenomenon: functionalist approach, conflict theory, symbolic-interactionist approach, phenomenological approach, and comparative-historical approach. ${ }^{11}$

The functionalist approach aims at identifying the social functions that humour fulfils in a society. The anthropologist Alfred Radcliffe-Brown sees humour as having a tensionrelieving function in society. ${ }^{12}$ Other researchers, such as George Paton and Chris Powel, argue that humour performs a social control function. ${ }^{13}$ Rose Coser attributes to humour another function, that of social cohesion. Humour, she says, can help create solidarity between people who share common experiences. At the same time, humour can also lead to the consolidation of social discrepancies, to the intensification of some differences. Thus, Coser concludes, depending on the context, humour can fulfil either an integrative function or an exclusion one. ${ }^{14}$

The phenomenological approach to humour emerged in the 1970s and made a great contribution in this field in terms of methodology, historical analysis, content analysis, and ethnographic study. ${ }^{15}$ This approach views humour as a world perspective, that is, a specific type of discourse, called humorous discourse. ${ }^{16}$ The most important contributions to the study of humour from a phenomenological perspective belong to Anton Zijderveld, ${ }^{17}$ Mikhail

${ }_{9}^{9}$ Sigmund Freud, Der Witz. und seine Beriebung zum Unbewnßten [Jokes and their relation to the Unconscious] (Deuticke, Leipzig, 1905).

${ }^{10}$ Giselinde Kuipers, 'The sociology of humour,' in, Victor Raskin (ed.), The Primer of Humour Research, pp.365-

402 (Mouton de Gruyter, Berlin/New York, 2008), p.368.

${ }^{11}$ Ibid.

${ }^{12}$ Alfred Radcliffe-Brown, ‘On Joking Relationship,' Journal of the International African Institute 13.3 (1940).

${ }^{13}$ Chris Powel, George Paton (ed.), Humour in Society: Resistance and Control (MacMillan, Basingstoke, 1988).

${ }^{14}$ Rose Coser, 'Some social functions of laughter: A study of humour in a hospital setting,' Human Relations 12.2 (1959), p.172.

${ }^{15}$ Kuipers, 'The sociology of humour,' pp. 380.

${ }^{16}$ Ibid.

${ }^{17}$ Anton Zijderveld, Reality in a Looking-glass: Rationality through an Analysis of Traditional Folly (Routledge, London, 1982).

(C) School of Slavonic and Eastern European Studies, University College London, 2018. 
Ignat - The Discourse on Humour In the Romanian Press Between 1948-1965

Bakhtin, ${ }^{18}$ and Michael Mulkay. ${ }^{19}$ If Mikhail Bakhtin talks about humour as an alternative to the official culture, so having a subversive function, Michael Mulkay believes that humour helps maintain the existing social structure, so having a conservative role. ${ }^{20}$

The first comedy film ever made is considered to be The Sprinkler Sprinkled, ${ }^{21}$ produced and directed by the Lumière brothers, Louis and Auguste, in 1895. Since then comedy films have grown in number and popularity. Humour has also been and continues to be used not only in comedy films, but also in other cinematic genres such as horror films, Western films, and dramatic movies; therefore film comedy can be considered both a genre and a mode. The first studies dedicated to film comedy date back to the 1970s, but only since the 1990s have these studies begun to multiply and diversify. This relative delay in film comedy studies can be attributed to the bias that has been associated with film comedy ever since its advent, according to which this genre is not serious enough to merit an in-depth study since it is just an easy form of entertainment.

The development of cultural history and popular (and mass) culture studies has led to a gradual reconsideration of film comedy in the sense of including it within the 'serious' domains of research. We are currently seeing a wide variety of issues tackled in film comedy studies. First of all, it is worth mentioning the anthologies dedicated to comedy, works that deal exhaustively with cinematic comedy produced in various cultural spaces as well as in different time periods. ${ }^{22}$ There have also been several studies on slapstick, gag-based comedy. ${ }^{23}$ These studies focus mainly on the film comedy made in the silent era. Other

18 Mikhail Bakhtin, Rabelais and his world (M.I.T. Press, Cambridge, 1968).

${ }^{19}$ Michael Mulkay, On Humour: Its Nature and Place in Modern Society (Polity Press, Oxford, 1988).

${ }^{20}$ Kuipers, 'The sociology of humour,' pp. 381.

${ }^{21}$ Original French title: L'Arroseur Arrosé.

22 Gerald Mast, The Comic Mind: Comedy and the Movies (University Press of Chicago, Chicago, 1979); Kristine Karnick, Henry Jenkins (ed.), Classical Hollywood Comedy (Routledge, New York, 1995); Andrew Horton, Joanna E.Rapf (ed.), A Companion to Film Comedy (Wiley-Blackwell, Oxford, 2013); Geoff King, Film Comedy (Wallflower Press, London, 2002).

23 Alan Dale, Comedy Is A Man in Trouble. Slapstick in American Movies (University of Minnesota Press, Minneapolis, 2000); Saul Austerlitz, Another Fine Mess. A History of American Film Comedy (Chicago Review Press, Chicago, 2010); Alan Bilton, Silent Comedy Film and American Culture (Palgrave MacMillan, London, 2013).

(C) School of Slavonic and Eastern European Studies, University College London, 2018. 
significant numbers of studies focus on romantic comedy. ${ }^{24}$ The ideological significance of comedy films is also an issue under research. ${ }^{25}$ There are also studies dedicated exclusively to film comedy in a socialist state. ${ }^{26}$

\section{HUMOUR THROUGH SATIRE: 1948-1953}

The discourse dominating the period within 1948-1953 is one in which humour is a weapon to be used against negative attitudes in society, the aftermath of the old regime. The dominant ideas on satirical comedy in this period are the following: the didactic role of humour in society; the rejection of theories which considered conflict to be an irrelevant concept for the new society; the emphasis on the use of satire for ridiculing bourgeois ways of thinking; and the appeal to classical authors, who wrote when Romania was still a monarchy, for illustrating the correct way in which attitudes believed to be negative to society were to be ridiculed.

This is the period during which the Romanian communist regime formulates its official discourse on humour. ${ }^{27}$ It is seen as a fresh new beginning for a new regime, a time of tumultuous social, political, economic, and cultural changes strongly influenced by the Soviet Union. $^{28}$ This context, coupled with the defining quality of humour - ambiguity ${ }^{29}-$ makes for a great caution with which this concept is discussed. ${ }^{30}$ However, articles which analyse

24 Claire Mortimer, Romantic Comedy (Routledge, London, 2010); Leger Grindon, Hollywood Romantic Comedy: Conventions, History and Controversies (Wiley-Blackwell, Oxford, 2011); James Harvey, Romantic Comedy in Hollywood: from Lubitsch to Sturges (Da Capo Press, 1998).

25 Christopher Beach, Class, Language, and American Film Comedy (Cambridge University Press, Cambridge, 2004).

26 Andrew Horton, Inside Soviet Film Satire: Laughter with a Lash (Cambridge University Press, 1993).

27 Due to the lack of film comedies in this period, the discourse on humour does not refer to this type of comedy. With the release of the first Romanian socialist comedy films by 1954-1955, the discourse on humour becomes more and more concerned with this type of comedy.

${ }^{28}$ During the period between 1948 and 1953, the Romanian Communist regime is completely dependent on the USSR. The economy is transformed according to the Stalinist model and controlled by the USSR through a joint Romanian-Soviet venture called SovRoms. Politically, Romania adopts the Soviet model: the new Romanian Constitution follows the Soviet Constitution from 1936. This period means also the Sovietization of Romanian culture: the adoption of Socialist Realism as the official aesthetic doctrine as well as the Sovietization of the artistic creations, are the most important changes that reflect the new trend in the field of culture.

${ }^{29}$ Andrew Horton, Inside Soviet Film Satire: Laughter with a lash, p.3.

${ }^{30}$ In the absence of a socialist model of humour, literary critics were at a loss regarding what forms of humour were to be regarded as 'acceptable' in the new society.

(C) School of Slavonic and Eastern European Studies, University College London, 2018. 
humour and its role in shaping a new society, as well as the functions and the manifestations it must embody, start to appear in the press. ${ }^{31}$ As to the types of humour, the form which is favoured in this period is the satirical comedy, which ridicules human attitudes considered negative to society. The film historian Alekandr Prokhorov argues that satire was also the form of humour privileged by Stalin's cultural revolution during the last years of the 1920s, due to its biting quality of attacking values and attitudes considered unhealthy by the regime. ${ }^{32}$

The satirical comedy shaped by the public discourse of this period is a form of criticism and self-criticism, directed towards negative attitudes in society. This form of criticism through satire - is performed in a comical manner, humour being the element which is added to the canonical notion of criticism and self-criticism. ${ }^{33}$ This notion makes its way into Romanian public discourse from the second half of the 1940s onwards. Gheorghe Gheorghiu-Dej, the Romanian communist leader, explains the role of this 'weapon' in a speech he gives in 1949:

To strengthen the unity of the working class, one must cultivate a sense of criticism and self-criticism; also, we must esteem and cherish the principle of democracy within trade unions and other mass organizations of the working people. ${ }^{34}$

In another speech he gives at the beginning of 1953, the Romanian communist leader reiterates the importance of cultivating a critical attitude among working people:

Self-criticism must be practiced on a large scale, giving the proletariat the opportunity to help party members improve their work and see their own shortcomings and errors. Any attempt at subverting criticism and self-criticism, any endeavour to throttle this critical attitude spreading from the working class onwards must be vigorously repelled. ${ }^{35}$

31 'Our Playwrights against bureacratism,' 'Two Satires on bureaucratism,' 'Some problems regarding the satirical literature,' 'Following the great tradition of our Satire.'

32 Aleksandr Prokhorov, 'Cinema of Attractions versus Narrative Cinema: Leonid Gaidai's Comedies and El'dar Riazanov's Satires of the 1960s,' Slavic Review 62.3 (2003), pp. 457-458.

33 In Marxist ideology, criticism and self-criticism was seen as an idiom and not as two separate notions.

34 Gheorghe Gheorghiu-Dej, Articole și cuvântări [Articles and Speeches] (București: Editura de Stat pentru Literatură Politică, 1956), p.291.

${ }^{35}$ Ibid, p.569. 
Ignat - The Discourse on Humour In the Romanian Press Between 1948-1965

Finding the right balance between ridiculing the old and portraying the new is a continuous process of the official discourse on humour of this period. In a 1948 article which discusses two Soviet satirical plays recently staged in Bucharest, Simion Alterescu makes a sharp distinction between the bourgeois satirical comedy ${ }^{36}$ and the Soviet satirical comedy. The former is described as 'rotten, absurd, stemming in a playwright's corrupted imagination and not in the day-to-day reality which ought to be ridiculed, ${ }^{37}$ whilst the latter manages to 'fully eliminate the aimlessness of the quid pro quo' and aims at 'becoming a faithful mirror to society' - even more, this latter sort of comedy is 'endowed with a didactic value, placing society and human types under a critical scrutiny. ${ }^{338}$ Alterescu's article emphasizes an essential characteristic of the official satirical humour of this period - its didactic purpose in society, realized through its critical gaze upon attitudes, mentalities, and ways of behaving held to be inappropriate. An example of such a damaging attitude for society - ridiculed by satirical comedies in this period - is bureaucratism, 'a plague which has been much fought against and which is still strongly opposed by the Soviet Union and by us today. ${ }^{39}$ The attack on bureaucratism through satirical comedies is characteristic of the humorous discourse promoted by Contemporanul magazine at the end of the 1940s. An illustration of this tendency is the 1949 article Ourplaywrights against bureaucratism (Dramaturgii noștri combat birocratismul). The author argues that a well-conceived satirical comedy criticizes bureaucratism in a socialist setting, such as a factory through the conflict between old functionaries, idle, indifferent, corrupted and ignorant of the factory's interests ${ }^{40}$ and the new type of functionary, 'engaged by his work, conscious of his responsibility to the factory's proper functioning and aware of the general importance of his attitude for society. ${ }^{41}$ Satire is created by using humour to ridicule bureaucratism, a fact which makes satirical comedy constitute:

\footnotetext{
${ }^{36}$ By the term 'bourgeois,' the author refers both to the satirical comedies made in the West, but also to those made in Romania before the war.

37 Simion Alterescu, 'Două satire la adresa birocratismului' [Two Satires on bureaucratism] Contemporanul 109 (29 October 1948).

38 Ibid.

${ }^{39}$ Ibid.

40 Simion Alterescu, 'Dramaturgii nostri combat birocratismul' [Our playwrights against bureacratism] Contemporanul 125 (25 February 1949).

41 Ibid.
} 
Ignat - The Discourse on Humour In the Romanian Press Between 1948-1965

an opening of new doors in comparison with the past national comedy, through its interests and fresh new characters, but especially through its use of humour not for humour's sake, but to serve an idea, to denounce a defect and vigorously fight against it. $^{42}$

Alterescu argues that the dichotomous portrayal of the world in satirical comedies, one in which the new confronts the old, is made in a disproportionate manner. Playwrights tended to construct negative characters in a much more complex manner, whilst positive characters were, in most cases, 'artificial and faintly outlined. ${ }^{43}$ In another article, Cezar Petrescu ${ }^{44}$ argues that humour should have a clear aim, and not be a gratuitous act, used for the sake of entertainment. Its aim is to ridicule unbealtby attitudes in society, as Ion Luca Caragiale and Nicolai Gogol ${ }^{45}$ have made in their satirical work:

Both have the same promptness in their dialogues, the same precision in portraying character types, the same use of irony, which gives the appearance of tolerance and light humour, so that it can later dismantle a painful and bitter message. ${ }^{46}$

The annual progress report of the PCUS Central Committee, which G.M. Malenkov presented at the $19^{\text {th }}$ Congress in $1952,{ }^{47}$ had a great influence on the Romanian discourse on satirical comedy. Here, Malenkov urged artists to use criticism and self-criticism to fight

${ }^{42}$ Ibid.

${ }^{43}$ Ibid.

${ }^{44}$ Cezar Petrescu, 'Caragiale și marii clasici rusi' [Caragiale and the Great Russian Writers], Contemporanul 4 (25 January 1952).

${ }^{45}$ Through the association between Ion Luca Caragiale and Nicolai Gogol, the discourse seeks to establish a common bond between the pre-revolutionary Romanian avant-garde and the pre-revolutionary Russian avant-garde. Gogol (along with Anton Chekhov) was considered the fiercest critic of the bourgeois regime in pre-Soviet Russia. In the same way, Caragiale was considered the most important critic of the bourgeois regime in Romania. Both Caragiale and Gogol lived in the nineteenth century.

${ }^{46}$ Ibid.

${ }^{47}$ G.M. Malenkov, Raportul de activitate al Comitetului Central al P.C.(b) al U.R.S.S. la Congresul al XIX-lea al partidului [The annual report of the Central Committee at the 19th Congress of the CPSU] (București: Editura pentru Literatură Politică, 1952).

(C) School of Slavonic and Eastern European Studies, University College London, 2018. 
against negative phenomena in society, such as bureaucratism. ${ }^{48}$ Through satire, 'destructive and unwholesome elements must be exposed, in order to be removed, annihilated and so ensure a continuous and successful progress. ${ }^{49}$ As soon as this document appears, Contemporanul publishes a series of articles ${ }^{50}$ which further stress the importance of satire and fables in correcting unlawful elements in society. Thus, Silvian Iosifescu uses Malenkov's ideas and argues that negative elements in society must be 'branded with hot iron" ${ }^{51}$ through the use of satire. According to Iosifescu, the essence of humour is the contrast created between the appearance of a thing and the essence of the same, both portrayed simultaneously. ${ }^{52}$ In socialism, this comical contrast 'reveals the infiltrations of the old regime and of the vicious in society. ${ }^{53}$ Thus, this theory holds that satirical comedy must reveal the deficient essence of the old (that is, bourgeois attitudes), which contrasts with its apparent pleasing image.

One of the most important ideas of the humorous discourse in this period is that socialist humour must have a purpose. Eugen Luca argues for a more extended use of satirical comedy, neglected in Romanian literature due to 'fake and harmful theories, in circulation until recently, which viewed satirical literature as useless within the new social and political conditions and humorous literature as reprehensible, in general. ${ }^{54}$ Silvian Iosifescu also argues that it is wrong to consider satirical comedy as useless in this new society. Without the conflict created through satire, artists would be prone to illustrate only positive aspects in society, and neglect the negative. ${ }^{55}$ He also makes a distinction between a form of benevolent humour and a more cruel form of humour. The first is used to ridicule essentially positive characters, which may nevertheless have minor flaws in their attitude, whilst the

${ }^{48}$ Ibid, pp.96-103.

${ }^{49}$ Ibid, p. 96.

50 'Să continuăm marea tradiție a satirei noastre,' 'Reînvierea unui gen literar,' 'Unele probleme ale creației literare satirice,' 'Discuții asupra problemelor poeziei, schiței și comediei satirice,' 'Procedeul exagerării în satiră.'

51 Silvian Iosifescu, 'Unele probleme ale creației literare satirice' [Some problems regarding the satirical literature] Contemporanul 19 (8 May 1953).

52 Ibid.

${ }^{53}$ Ibid.

${ }^{54}$ Eugen Luca, 'Reînvierea unui gen literar' [Revival of a genre] Contemporanul 38(363) (18 September 1953).

${ }^{55}$ Iosifescu, 'Unele probleme ale creației literare satirice' [Some problems regarding the satirical literature]. 
second attacks 'class enemies' - thus, negative characters. ${ }^{56}$ The distinction between a form of benevolent humour, understood as light criticism directed at petty mistakes in the new society, and a much harsher form targeting the old bourgeoisie, is also to be found in the Soviet Union, and was first made by Anatoly Lunacharsky ${ }^{57}$ at the end of the 1920s in the context of Stalin's cultural revolution. ${ }^{58}$ Iosifescu also reiterates the idea that humour is not a gratuitous act - if used in such a way, it might erroneously create 'nice' negative characters. ${ }^{59}$ Sketchy negative characters are also one of the problems satirical comedy raises, since most of the times negative characters are unrealistic, Iosifescu writes. To avoid such a problem, such characters must be created so as to appear authentic at the beginning, and as the action unfolds, try to hide their own essence as much as possible, so that at the very end their real personality is revealed - hence creating the comical contrast characteristic of satirical comedies. ${ }^{60}$

Lucian Raicu is another author who stresses the importance of satire in an article with an interesting title - 'Continuing our long tradition of satire' ${ }^{61}$ - published in Contemporanul in 1953. Making references to Romanian classics (such as Ion Luca Caragiale or Grigore Alexandrescu), he argues that their satire constituted a powerful social critique of the old regime in Romania: 'there never existed any negative type in our society, whose critical and satirical reflection escaped literature.' ${ }^{62}$ In the new regime, Raicu continues, the aim of satirical literature is to 'defend the existent state of affairs and uproot from this new, progressive society what is rotten and petrified. ${ }^{, 63}$

Raicu also describes the function of satire:

56 Ibid.

57 The Soviet People's Commissar of Education in the 1920s, responsible for culture and education.

58 Taylor, 'Soviet Socialist Realism,' p.455.

${ }^{59}$ Iosifescu, 'Some problems regarding the satirical literature.'

${ }^{60}$ Ibid.

61 Lucian Raicu, 'Să continuăm marea tradiție a satirei noastre' [Following the great tradition of our Satire] Contemporanul 16 (341) (17 April 1953).

${ }^{62}$ Ibid.

${ }^{63}$ Ibid. 
Ignat - The Discourse on Humour In the Romanian Press Between 1948-1965

according to the examples provided by our classics, one must create negative types to mirror the decay of old classes, together with their decrepit modes of thinking; these satirical types will help our workers recognize and fight their enemies with greater force. ${ }^{64}$

Perhaps the most interesting element in Raicu's article is the inventory of negative satirical types which he argues Romanian art and literature should be creating: the landowner or the capitalist, who no longer holds power; the kulak, 'treacherous and slick, hateful of social changes;' the bureaucrat, 'an enemy to progress;' the intellectual, 'a cosmopolitan and a skeptic, he is a class enemy as well;' the blabber; and the hypocrite, 'immune to criticism which comes from the ground level and society and vengeful towards those who criticize him. ${ }^{65}$

\section{FROM HUMOUR THROUGH SATIRE TO COMEDY ILLUSTRATING POSITIVE CHARACTERS: 1953-1955}

Starting with the second half of 1953, one can note a slight change of perspective in the official Romanian discourse on humour - a change which will become significant in the following year. A new form of humour emerges: the optimistic comedy, which illustrates the new society and which is centred on positive heroes, who are portrayed as either fighting against old ways of thinking, or being gently ridiculed for their minor faults. Thus, unlike the previous period, when the aim of comedy was to ridicule negative characters, now positive heroes are the main intent, as they are the forces bringing change to society. Satirical comedy is by no means extinct by that point - the two views on humour co-exist - but in this period the focus in the official discourse is on the form of humour which depicts, in an optimistic fashion, the new society. The official discourse on film comedy is also formulated during this period, as the first Romanian communist comedy films, both feature length and short feature, are released: Something Happened to Marincea (Cu Marincea e ceva, 1954), Inspector 10 Popescu (Popescu 10 in control, 1955), and Our Director (Directorul nostru, 1955).

This is a rather uncertain period, with events in the Soviet Union having left their mark on the Soviet satellite states (Romania included). After Stalin's death in 1953, the new

${ }^{64}$ Ibid.
${ }^{65}$ Ibid.

(C) School of Slavonic and Eastern European Studies, University College London, 2018. 
collective leadership formed in Moscow announced the 'New Course, ${ }^{66}$ through which a series of reforming measures in the party, society, economy, and external politics were issued. ${ }^{67}$ Due to some degree of uncertainty, the regime in Bucharest had adopted a more relaxed stance on the actual application of recent Soviet decisions, an attitude which has caused historians to characterize this period as one of 'slight liberalization. ${ }^{68}$

In an article discussing the problems of satirical comedy, published in Contemporanul, the author finds that the play which he analyses (Mielul turbat by Aurel Baranga) follows the demands of Socialist Realist comedies. ${ }^{69}$ Nevertheless, the author goes on, an improvement of Romanian satirical comedies is necessary, and this improvement can be made through a more clear portrayal of positive characters and their dominant role in society. ${ }^{70}$ Following a period in which the discourse on satire set the critique of negative phenomena as the main aim of the genre, this article brings a fresh nuance to the discourse, as it argues in favour of positive characters - they are the ones who need to be at the core of comedy. Another essay which appears in 1954, in the same magazine, makes several favourable remarks on the portrayal of the positive character in Mielul turbat: he is 'joyful and optimistic, [...] and the audience will not laugh of him, but with him, mocking the bureaucrats and all their nonsense. ${ }^{71}$

The official discourse in this period presents satire as a form of 'affirming superior forms of conscience, ${ }^{72}$ as stated in a Soviet article which was translated and published in Contemporanul. The same article further argues that a good satirical comedy creates positive

${ }^{66}$ For a detailed analysis of the politics of the New Course and its effects on Romanian communist regime, see: Ghiță Ionescu, Comunismul în România [Communism in Rumania] (Bucuresti: Editura Litera, 1994), pp.252-286 and Dan Cătănuș, Tot mai departe de Moscova [Further away from Moscow] (Bucuresti: Insititul Național pentru studiul Totalitarismului, 2011), pp.52-63.

${ }^{67}$ Cătănuș, Tot mai departe de Moscova [Further away from Moscow], p.53.

68 Ibid, pp.54-55.

69 'Discuții asupra problemelor poeziei, schiței și comediei satirice' [Discussions on poetry and satirical comedy] Contemporanul 27(352) (3 July 1953).

${ }^{70}$ Ibid.

71 Sică Alexandrescu, 'Un succes al literaturii noastre satirice' [A Triumph of our satirical literature] Contemporanul 18(395) (30 April 1954).

72 Alexandr Iliadi, 'Scopul și mijloacele satirei' [The Purpose of Satire] Contemporanul 47(424) (19 November 1954).

(C) School of Slavonic and Eastern European Studies, University College London, 2018. 
Ignat - The Discourse on Humour In the Romanian Press Between 1948-1965

characters so as to appear far superior to negative ones. ${ }^{73}$ Also, a satire which did not have a positive character would be unconceivable, since it would not be faithful to reality. ${ }^{74}$

Several articles stressing the importance of the positive character in comedies are published in the press throughout 1954. On some aspects of the positive character ('Despre unele probleme ale eroului pozitiv'), written by Petre Luscalov for Contemporanul is an example of this new concern. Luscalov argues that the 'positive' character is missing from Romanian literature due to authors having a faulty idea about what it represents:

Creating a positive character starts from a pre-established list of qualities - he must be vigilant, competitive, heroic, ready to sacrifice himself, and this makes him somehow dogmatic. $^{75}$

Such a defective understanding of character portrayal makes positive heroes 'pale and superficial, ${ }^{, 76}$ whilst negative ones are 'complex and well defined. ${ }^{77}$

Screen comedy is included in the official discourse on humour in 1954, when Gheorghe Turcu's short feature Something Happened to Marincea is released. Analyzing the film, Mircea Drăgan ${ }^{78}$ makes some observations regarding satirical comedy on screen. Something Happened To Marincea criticises some negative aspects found in society, such as bureaucratism, servility, or the lack of courage, and therefore has the merit of revealing the fact that only in a communist society such negative phenomena are impossible, and that characters who engage in such matters are ridiculous. ${ }^{79}$ As Drăgan puts it, 'the more powerfully the film exposes the old, the more it asserts the new. ${ }^{80}$ Nevertheless, Turcu's film does not succeed in exploring the full range of humorous possibilities offered by the script, Drăgan concludes. Here the author

73 Ibid.

${ }^{74}$ Ibid.

75 Petre Luscalov, 'Despre unele probleme ale eroului pozitiv' [On some aspects of the positive character] Contemporanul 41(418) (8 October 1954).

${ }^{76}$ Ibid.

77 Ibid.

78 A Romanian film director.

79 Mircea Drăgan, 'Realizarea comicului în filmul Cu Marincea e ceva' [The use of comic devices in the film There is something about Marincea] Probleme de cinematografie 6 (June 1954), p.50.

${ }^{80} \mathrm{Ibid}$.

(C) School of Slavonic and Eastern European Studies, University College London, 2018. 
Ignat - The Discourse on Humour In the Romanian Press Between 1948-1965

is especially referring to negative phenomena being exposed, a process usually achieved by means of humour, a technique this film ignores. ${ }^{81}$ Al. Boiangiu's review from Contemporanul considers the film to be 'a good and didactic one, ${ }^{82}$ with the positive hero being presented in an original way: ${ }^{83}$ he doesn't appear in any scene, but he is always present through the other characters' constant reference to him. Boiangiu argues that the originality of the positive hero's portrayal makes for a satisfying illustration of the new. ${ }^{84}$

The fact that this is a transitional period, during which the official discourse on humour moves from asserting the need to illustrate the new to ridiculing negative aspects of society, is confirmed in an article published in Probleme de cinematografie in 1955. The author of this article believes that the main function of humour is to criticize negative aspects in society: 'the most important characteristic of satire is that it doesn't directly proclaim a positive ideal, but indirectly affirms it by negating unwholesome phenomena. ${ }^{, 85}$ Thus, the idea according to which the role of comedy is to illustrate the new, to represent positive characters and not negative aspects in society is considered to be 'idyllic.' 86

Returning to a discussion of screen comedy, the review of Directorul nostru ${ }^{87}$ in Contemporanul criticizes the way satire is used in the film. ${ }^{88}$ What is faulty in the use of satire here, the author argues, is that it creates ambiguity, making it difficult for the audience to realize who is being ridiculed and what are the purposes driving each character (negative or positive). ${ }^{89}$ Another issue the film raises is that its positive characters are created in a serious and not humorous manner, whilst its negative characters are depicted from a comical point of view. ${ }^{90}$ The critic argues that due to these shortcomings, the film fails to provide an

${ }^{81}$ Ibid.

82 Al. Boiangiu, 'Cu Marincea e ceva' [There is something about Marincea] Contemporanul 36(413) (3 September 1954).

83 Ibid.

84 Ibid.

85 Titus Mesaroșiu, 'Mijloace de expresie în reportajul cinematografic satiric' [Means of expression in the satirical film] Probleme de cinematografie 5 (May 1955), p.46.

86 Ibid, p.45.

87 The first feature length satirical comedy film made in Romania during the communist regime.

88 Mircea Drăgan, 'Directorul nostru' [Our Director] Contemporanul 14(444) (8 April 1955).

${ }^{89}$ Ibid.

${ }^{90}$ Ibid.

(C) School of Slavonic and Eastern European Studies, University College London, 2018. 
Ignat - The Discourse on Humour In the Romanian Press Between 1948-1965

optimistic message (as it should) - instead, it confirms the idea that negative, fictitious characters, like the ones found in this film, have a substantial presence in real life as well.

If, at the end of the 1940s, the critique of negative phenomena in society through satirical comedy was encouraged, without stating the necessity of illustrating the new as well, in this period the official discourse tilts the balance in favour of showing the new society by means of humour. The first screen comedies were largely influenced by the discourse which favoured the use of humour through satire - but in this period, a change in perspective in the official discourse on film urges new productions to show the new society in a more optimistic and less critical manner. Simion Macovei's essay in Probleme de cinematografie (1955) ${ }^{91}$ gives an outline of the most important characteristics of screen comedy at this time. First, he argues that the ideology behind Romanian cinema is wrong, since it has only emphasized the negative aspects of society, leaving out the positive ones. ${ }^{92}$ The role of screen comedy, Macovei goes on, is to portray the 'positive heroes' of society, those who have become exemplary figures of their time, and should not aim only at ridiculing the negative. ${ }^{93}$ Furthermore, comedies should portray positive characters in an offensive attitude, launched towards creating something completely new - as happens in non-comical films, such as The Valley Resounds (Răsună valea), Our Village (În sat la noi), Life Wins (Viața invinge), and Ionutz. Brigade (Brigada lui Ionut). Thus, positive characters should be assigned an active role and not a passive one. ${ }^{94}$ The positive character should also evolve on an optimistic background laughing and cheerfulness are significant aspects of the new socialist life:

Our film production should seek to create lighter, more cheerful and optimistic comedies, with a new, free and happy life pulsing in them, and with positive characters blooming in these circumstances and building the socialist world. ${ }^{95}$

\footnotetext{
${ }^{91}$ Simion Macovei, 'În legătură cu eroul pozitiv în comediile noastre cinematografice' [On the positive character of our film comedy] Probleme de cinematografice 7 (July 1955).

${ }^{92}$ Ibid, pp.43-44.

${ }^{93}$ Ibid, pp.44-45.

${ }^{94}$ Simion Macovei, 'În legătură cu eroul pozitiv în comediile noastre cinematografice' [On the positive character of our film comedy], p.45.

${ }^{95} \mathrm{Ibid}, \mathrm{p} .49$.
} 
Ignat - The Discourse on Humour In the Romanian Press Between 1948-1965

Bright comedy, anchored in the present moment and meant to portray the new society and positive characters, leaving aside the critique of what is negative, is the main theme of the discourse on humour in this period.

\section{THE USE OF HUMOUR IN ‘OPTIMISTIC COMEDIES’ OR ‘LIGHT SATIRE’: 1956-1965}

The official discourse on humour in this period can be described as both more homogeneous and more diversified at the same time. The type of humour advanced by the art and criticism of this period is one which reflects the new society, with its essentially positive figures, in an optimistic and joyful manner. Satire is, once again, part of the story, but not as a way of harshly ridiculing the remains of the old regime, as was the case in 1948-1953. During this period, satirical humour is much more benevolent towards characters which are reasonable at heart, but which might have slightly departed from the right path. Through the early half of the 1960s, the discourse on humour begins to emphasize a new concept, the collective positive character.

From a cultural point of view, this period brought an expansion of artistic forms, especially in cinematography, where the annual production of feature length movies grew significantly. ${ }^{96}$ What is even more important for the purpose of this article is, of course, the development of Romanian film comedy. In this respect, one can note the appearance of more and more comedies whose subject is placed in contemporary Romania and whose positive characters are the most important - all of which are portrayed in an optimistic way. ${ }^{97}$ In this context, the official discourse on humour of this period is increasingly centred on film comedies. Even more, the discourse will revive the slapstick comedy, a characteristic form of comedy in silent film.

96 For detailed statistics of Romanian feature film production during the communist regime, see: Grid Modorcea, Dicționarul filmului românesc de ficțiune [The Dictionary of the Romanian Feature Film] (Bucuresti: Cartea Românească, 2004).

97 Between 1956-1965, the Romanian film industry produced 12 feature-length comedy films with the subject matter set in contemporary Romania: On My Responsibility (Pe răspunderea mea), A Little Story (O mică intâmplare), Hello! Wrong Number (Alo..ați greșit numărul!), Our Lads (Băieții noștri), I Don't Want to Get Married (Nu vreau să mă insor), Poste restante (Post-restant), Two Lads with a Heart of Gold (Doi băieți ca pâinea caldă), Holidays at a Seaside (Vacanță la mare), At the Age of Love (La vârsta dragostei), A Midsummer Day's Smile (Un surâs în plină vară), Love at Freezing Point (Dragoste la zero grade), Gaudeamus igitur.

(C) School of Slavonic and Eastern European Studies, University College London, 2018. 
Ignat - The Discourse on Humour In the Romanian Press Between 1948-1965

The political context of these years is dominated by a discourse emphasizing 'DeStalinization,' which came about as a result of Khrushchev's so-called 'Secret Speech' of 1956, in which the communist leader condemned Stalin's crimes. ${ }^{98}$ The first stage of Romanian deStalinization took place in 1956 and was led by Gheorghe Gheorghiu-Dej, as his own manoeuvre to gain more power in the party. ${ }^{99}$ A real de-Stalinization, however, came only after the Plenary Session of the Central Committee of the Romanian Workers Party, at the end of 1961, argues Dan Cătănuș. ${ }^{100}$ At the same time, this period will also lead to a gradual rejection of the Soviet Union, ${ }^{101}$ a move made more obvious in the years after 1961 and advocated by the Romanian Workers Party Declaration of $1964 .{ }^{102}$

The inclusion of light satire in optimistic comedies becomes more visible once the film On My Responsibility (Pe răspunderea mea) is released in 1956. In a review published in Film magazine, Simion Macovei describes the film as 'an optimistic, cheerful and instructive comedy, ${ }^{103}$ whose main intent is to ridicule 'the obstinacy and conceit' ${ }^{104}$ of young Dinu, a positive character at heart, but whose moral shortcomings threaten to 'atrophy his innate qualities,' if left unchecked. ${ }^{105}$ Ioana, the main positive character of the film, does not limit herself to criticizing Dinu's vices, but acts in a correct and concrete manner to reform him altogether. ${ }^{106}$ One can see in this discourse the main intents of optimistic comedy: the portrayal of a current situation in a pleasant manner, with positive characters taking actions to reintegrate within the collective those who have departed from it, due to minor moral faults.

98 The speech, originally entitled, On the Cult of Personality and Its Consequences,' was given at the 20th Congress of the Communist Party of the Soviet Union. See: Ionescu, Comunismul în România [Communism in Rumania], p.289.

99 Dan Cătănuș, 'Impactul raportului secret asupra conducerii PMR. Destalinizarea în România' [The effects of Secret Speech on the Romanian Workers Party. De-Stalinization in Romania] in, Lagărul comunist sub impactul destalinizărï: 1956 [The Eastern Bloc under De-Stalinization.1956] ed. Dan Cătănuș, Vasile Buga, (Bucuresti: Insititutul Național pentru studiul Totalitarismului, 2006), p.149.

100 Ibid, p.150.

${ }^{101}$ Ibid, p.22.

102 Ibid.,pp.333-340.

103 Simion Macovei, 'Pe răspunderea mea' [On my responsibility] Film 5 (May 1956), p.11.

104 Ibid.

105 Ibid.

106 Ibid, p.12.

(C) School of Slavonic and Eastern European Studies, University College London, 2018. 
Ignat - The Discourse on Humour In the Romanian Press Between 1948-1965

The same discourse surfaces in the review of Hello! Wrong Number (Alo...at i greșit numărul!), a comedy released two years later, in 1958. The reviewer notes that the movie is both 'entertaining and thoughtful, instructive. ${ }^{107}$ It is also clear that the principles which underpin this comedy are sound - satire works to rectify the inappropriate behaviour of a character who is 'essentially positive and who still has a chance. ${ }^{, 108}$ The author also praises the portrayal of positive characters which are 'independent, natural, convincing, charismatic'109 and the role of the collective in reforming the same character's unhealthy attitudes: 'the powerful normative presence of the collective is felt throughout the film [..]. Victor will become a completely new man, thanks to it. ${ }^{110}$ Thus, a new humour discourse is asserted: bright comedy, which reflects the optimistic environment of the new society, is blended with light satire, which works to rectify slight errors in the conduct of essentially positive (not negative!) characters. Usually, this character is an individualistic young man, who is 'reformed' by the collective, represented by a female positive individual.

Another common idea of the discourse in this period is the emphasis on humour as an essentially serious phenomenon, ${ }^{111}$ even though its aim is to promote optimism and joyfulness. In an article from Contemporanul, published in 1957, Georgeta Horodincă argues that to represent a serious matter comically is not to underplay it - on the contrary, humour has the capacity to reveal new and important aspects of that matter. ${ }^{112}$ As to the role of humour, Horodincă also stresses the importance of the positive character in a comedy's narrative. The same ideas are taken over by Vera Călin, who also believes in the serious essence of humour. ${ }^{113}$ Călin also makes a distinction between humour and irony - the first aims to provoke a 'kind, benevolent laughter towards a comical character who is essentially virtuous,' whilst the latter 'sanctions what is blameworthy, through laughter.'114

${ }^{107}$ Eugen Schileriu, ‘Alo..ați greșit numărul' [Hello..Wrong Number] Contemporanul 51(637) (26 December 1958).

108 Ibid.

109 Ibid.

${ }^{110}$ Ibid.

111 Georgeta Horodincă, 'Comicul minimalizează?’ [Humour scoffing at the world] Contemporanul 13(547) (29 March 1957).

112 Ibid.

113 Vera Călin, 'Râsul care nu depreciază’ [The underestimating power of humour] Contemporanul 15(549) (12 April 1957).

${ }^{114}$ Ibid.

(C) School of Slavonic and Eastern European Studies, University College London, 2018. 
Ignat - The Discourse on Humour In the Romanian Press Between 1948-1965

The idea of humour as a serious phenomenon, used for specific social purposes and not as a gratuitous ornament, had been a part of the Romanian humour discourse since the 1940s, and was still stressed in this period, thus proving itself to be a lasting notion. In 1959, an article in Contemporanul discussing a radio program on humour reiterates the idea of humour's social responsibility. The radio program has had a 'promising start,"115 the author argues, but departed from the real problems of Romanian citizens by engaging in a 'petty and hazy kind of humour, whose purpose is merely to stir laughter. ${ }^{116}$ The author argues that the purpose of humour is to be

fearless in revealing weaknesses in all areas of society so that they can be rectified; to ridicule regressive attitudes at work and create a general drift of opinion amongst workers in repudiating thieves, hooligans and those who waste common goods with their indifference. ${ }^{117}$

However, these negative attitudes must be criticized in a 'joyful manner,' ${ }^{118}$ using 'witty tunes, kind jokes, light satire and banter., 119

The humourous blend of optimistic comedy and satire, which criticizes what is 'anachronistic and obsolete, ${ }^{120}$ is still part of the discourse on humour at the beginning of the 1960s. What is interesting and new in the humour discourse during that period is that, together with the stress upon the positive character and its central role in socialist realist satirical comedy, ${ }^{121}$ critics start to contest the ridicule of bureaucratism and servility. Mockery towards such attitudes is no longer topical, as Radu Gurău argues in one of his articles in Contemporanul. ${ }^{122}$

Discussing film comedy in an article from 1961, Ion Barna pleads for 'optimistic comedy,' which originated in the Soviet Union and was founded by Grigori Aleksandrov (a

\footnotetext{
115 'Satira și umorul la radio' [Humour and Satire at the Radio] Contemporanul 46(684) (20 November 1959).

116 Ibid.

117 Ibid.

118 Ibid.

119 Ibid.

${ }^{120}$ Radu Gurău, 'Pentru comedie’ [For Comedy] Contemporanul 32(721) (5 August 1960).

${ }^{121}$ Ibid.

122 Ibid.
}

(C) School of Slavonic and Eastern European Studies, University College London, 2018. 
reference to his famous musical comedies of the 1930s: Jolly Fellows, Circus, and VolgaVolga $).{ }^{123}$ Optimism is the main characteristic of these Soviet comedies, Barna argues - but 'good comedy is always serious comedy.' ${ }^{24}$ The article also discusses two possible ways for the future development of Romanian film comedy: a series of satirical films created around a single character ('a present-day Păcală, ${ }^{125}$ who criticizes old and bad habits and rectifies them through satire ${ }^{126}$ ), or a revival of comedies from the 1920s, using slapstick humour and gags, 'as long as these serve a higher purpose and their humour is useful and agreeable. ${ }^{127}$ It is interesting to note that the discourse on humour tries to revive the slapstick comedy of the 1920s, even though 10 years before this type of humour was considered obsolete. The need to use elements of the slapstick comedy in films of this period - especially gags - is also stated in a collective review of the film I Don't Want to Get Married (Nu vreau să mă insor), written by workers at Electronica factory, published in Contemporanul. The authors praise the film for being joyful and optimistic, but they also regret the insufficient use of humour and the fact that 'few gags appear." ${ }^{128}$

The idea of criticizing certain 'improper' attitudes of Romanian youth through the use of a benevolent kind of satire permeates the discourse on humour of this whole period. Discussing Siciliana, a play by Aurel Baranga, Valentin Silvestru argues that this is a most useful satirical comedy, since 'there are young people in society which do not serve the cause of socialism as they might, by refusing to work after they have finished college or resenting country life.' ${ }^{129}$ Although the subject of the play is not necessarily typical for young people in Romania, Silvestru argues that 'satire has the duty of condemning any negative reality, however inessential. ${ }^{130}$ The play emphasizes the new society in a successful way, Silvestru

${ }^{123}$ Ion Barna, 'Vrem să râdem’ [We want to laugh] Contemporanul 9(751) (3 March 1961).

124 Ibid.

125 Păcală is a fictional comic character in Romanian folklore and literature. Among its various versions, the most popular Păcală character comes from the work of the Romanian writer Ion Creangă.

126 Ibid.

127 Ibid.

128 'Confruntarea cu publicul. Opinii despre filmul Nu vreau să mă însor' [Confrontation with the audience. Views on the film I don't want to gent married], Contemporanul 10(752) (10 March 1961).

129 Valentin Silvestru, 'Realism și comedie satirică' [Realism and satirical comedy] Contemporanul 3(745) (20 January 1961).

130 Ibid.

(C) School of Slavonic and Eastern European Studies, University College London, 2018. 
concludes, but it fails to create a comical denouement - instead, it produces both a dramatic ending and a positive character portrayed in a serious manner. ${ }^{131}$

In the first half of the 1960s, more and more theorists emphasized the deficient way in which Romanian filmmakers have understood the significance of the optimistic comedy coupled with benevolent satire. Mihai Tolu, reviewing the film Post-restant, argues that the comedy does not succeed in 'portraying the new element in the behaviour of the characters. ${ }^{132}$ According to Tolu, the main error of the movie is that it doesn't create a benevolent kind of humour around Puiu, the positive character of the movie, a shy, generous and creative engineer. ${ }^{133}$ Instead, it produces a comedy without a purpose around Dan, a character who has 'a bourgeois mentality and no aspirations. ${ }^{134}$ The author concludes that all of these result in a superficial and faulty portrayal of the positive character, unlike the one in Grigori Aleksandrov's Jolly Fellows. ${ }^{135}$

At the beginning of 1963, as interest in film comedy grows, Cinema magazine ${ }^{136}$ organizes a debate on Romanian film comedy amongst directors, actors, and scriptwriters. ${ }^{137}$ The participants unanimously agree on the huge popularity of the comic genre among the Romanian audience, but also deplore the low artistic quality of the films' production. Ioan Grigorescu argues that Romanian film comedies make use of 'frivolous jokes and subjects, which could have taken place anywhere and at any other time. ${ }^{138}$ Likewise, for the actor Grigore Vasiliu-Birlic the main problem is the lack of 'witty and imaginative' scripts dealing with 'everyday life, ${ }^{139}$ as well as the persistence of a prejudice: namely, that positive heroes have no place in film comedies. Manole Marcus, another filmmaker, argues that comedies made in this period only follow 'outdated patterns of old comedies created in the interwar period, set against a new background, but whose content has little relevance to our

\footnotetext{
131 Ibid.

132 Mihai Tolu, 'Post-restant,' Contemporanul 18(812) (4 May 1962).

${ }^{133}$ Ibid.

${ }^{134}$ Ibid.

135 Ibid.

${ }^{136}$ Cinema was a popular film magazine in Romania, created in January 1963.

137 'Comedia cinematografică românească la masa rotundă' [Round table on the Romanian comedy film], Cinema 4 (1963).

${ }^{138}$ Ibid.

139 Ibid.
} 
Ignat - The Discourse on Humour In the Romanian Press Between 1948-1965

contemporary.' ${ }^{140}$ 'The director Aurel Miheles identifies the major problem of Romanian comedy as 'the peripheral role which the positive character has in the comical unfolding of events, and its likewise insignificant part in the narrative. ${ }^{141}$ According to Miheles, another major problem of Romanian comedies at this time is the artificial distribution of positive and negative characters. ${ }^{142}$ The actor Radu Beligan identifies as a general characteristic of movies in Romania the use of peripheral topics in comedies - instead 'film comedies should take on key subjects in society,' he argues. ${ }^{143}$ The attitudes of those partaking in this debate makes for a critical discourse on film comedy which fails to comply with both ideology and aesthetic standards. The main critique of the debate is that the positive character - the central figure of optimistic comedy according to the discourse on humour - is insufficiently developed. Another way of interpreting this criticism is to view it as a reiteration of the main principles of the Romanian official discourse on humour, this time aiming at film comedy, the most popular genre in Romanian cinema from the 1960s onwards.

Towards the middle of the 1960s, film comedy discourse acknowledges once more the importance of movies from the interwar period. Apart from reviving Soviet film comedies from the 1930s, as I argued earlier, film critics from this period emphasize the need to explore slapstick comedies, akin to those made in the West in the 1920s and 1930s. Ana Maria Narti publishes several articles on this subject, all published in Contemporanul between 1963-1965. In one of them, she discusses the main principles of these films (making references to Grigori Aleksandrov, Charlie Chaplin, Rene Clair and Robert Youngson movies) and argues that 'their universe is not unreal, despite their phantasmagorical aspect the contradictions which are reflected in them are real. ${ }^{144}$ Other characteristics of these films are their visual vividness, their extreme exaggerations, and their eccentricity. ${ }^{145}$ Narti further argues that Grigori Aleksandrov's works brought more quality to film history by adding a political aim to them. Thus, Aleksandrov managed to create a type of humorous movie which

\footnotetext{
140 Ibid.

141 Ibid.

142 Ibid.

143 Ibid.

144 Ana Maria Narti, 'Noua tinerețe a unor vechi comedii,' [The heyday of the old comedy films] Contemporanul 13(859) (29 March 1963).

145 Ibid.
}

(C) School of Slavonic and Eastern European Studies, University College London, 2018. 
Ignat - The Discourse on Humour In the Romanian Press Between 1948-1965

succeeded in both ridiculing negative aspects of society as well as portraying the new society. ${ }^{146}$ In another article, Narti analyses film comedies from the silent era, a 'golden period of comedy, ${ }^{147}$ whose genius was never been equalled by sound film. ${ }^{148}$ The renewal of contemporary comedy is possible, Narti writes, if the primeval sources of comical films (e.g. slapstick comedy and its use of gags) were integrated into present-day film-making. ${ }^{149}$

Musical comedy also becomes part of the official discourse on humour by the middle of the 1960s. An article from Contemporanul, published at the end of 1963, provides a list of possible topics for musical comedies: 'the fight against the ordinary; young people's tastes and preferences; ridiculing grotesque models; the praise of modest artists as opposed to outdated celebrities; assert the rights of melody against hollow noises. ${ }^{150}$ Another article from Contemporanul, published at the beginning of 1964, argues that musical comedy 'inspires men, giving them the joy and optimism to keep living [...] it is the answer to the age-old need of the audience to see their beloved character, an open and simple (not simplistic!) man stepping cheerfully into his own life. ${ }^{, 151}$ Thus, one can note how this discourse also emphasizes the portrayal of society in an optimistic light, by adding music to comedy.

The release of Geo Saizescu's comedy A Midsummer Day's Smile (Un surâs în plină vară, 1964) constitutes another occasion for a discussion of humour. In a review from Contemporanul, Ion Mihăilanu celebrates the political correctness of this satirical comedy, which 'ridicules the individualism of the main character and thus justly places him in opposition to the virtue of collectivism ${ }^{, 152}$ - the effect of ridicule results from the contrast between the portrayal of individualism set against the benefits of collectivism. Nevertheless, the film is an optimistic comedy whose main character, Făniță, is an agreeable fellow, due to 'his potential virtues - wit, self-irony, a great capacity to fantasize about the future, an obstinacy which can be transformed into a powerful will and ingenuity which is not

146 Ibid.

${ }^{147}$ Ana Maria Narti, ‘Comedia cinematografică - o nouă vârstă de aur?’ [A new golden age for the film comedy?] Contemporanul 40(990) (1 October 1965).

148 Ibid.

149 Ibid.

150 I.Hristea, 'Dramaturgia filmului muzical' [Musical film narrative] Contemporanul 49(895) (6 December 1963).

${ }^{151}$ Cezar Grigoriu, 'Comedia cinematografică’ [Film Comedy] Contemporanul 4(902) (24 January 1964).

152 Ion Mihăileanu, 'Un surîs în plină vară’ [A midsummer's smile] Contemporanul 13(911) (27 March 1964).

(C) School of Slavonic and Eastern European Studies, University College London, 2018. 
synonymous with stupidity - all of which remain untarnished throughout the film. ${ }^{153}$ Inherent in this review are the two main components of the official discourse on humour of this period: optimistic comedy and benevolent satire. Also, the dichotomy between individualism and collectivism, more and more evident, replaces that of the old versus the new, as was present in the discourse of the 1950s.

Towards the end of 1964, Traian Selmaru publishes in Contemporanul an important article, On the hero of the satirical comedy, ${ }^{154}$ concerning the new typology of the positive hero promoted by the discourse on humour from the middle of the 1960s. He sets the discussion off by arguing that joyfulness is the characteristic state of being of communist societies, and thus a necessary condition for humour. After stating this primary condition, Șelmaru argues that the type of satire which only ridicules the old regime, without emphasizing the benefits of the new, is obsolete: 'one cannot authentically represent reality without showing how the new regime intelligently reveals the manoeuvres of the old. ${ }^{, 155}$ Giving more details as to what a correct portrayal of the new society involves, Selmaru claims that an individual positive hero is not relevant any more, since it doesn't provide an overall view of reality - a collective hero is much more appropriate for giving a more complex picture. Thus, the official discourse on humour turns from emphasizing the individual positive hero to praising the positive collective one.

\section{CONCLUSION}

Tracing the development of the official discourse on humour from 1948 to 1965, one can easily note that humour was a serious concern for the Romanian communist regime. In all three stages forming the overall discourse, humour is treated as a significant phenomenon, revealing important aspects of society. The use of humour through satire, a form promoted by the official discourse of 1948-1953, aimed at ridiculing attitudes and beliefs considered to be negative - in other words, remainders of the old regime. By promoting the idea that through humour one can sharply criticize everything considered to be vicious, the official

153 Ibid.

154 Traian Șelmaru, 'Însemnări despre eroul comediei satirice' [On the hero of the satirical comedy] Contemporanul 36(934) (4 September 1964).

155 Ibid.

(C) School of Slavonic and Eastern European Studies, University College London, 2018. 
Ignat - The Discourse on Humour In the Romanian Press Between 1948-1965

discourse attributes to humour a 'purifying function' in society. However, this perspective changes in 1953-1955, when the idea that humour should also illustrate the positive aspects of society, and not merely ridicule the negative, makes its way into the official discourse. Thus, from the middle of the 1950s to the middle of the 1960s, the optimistic comedy and the benevolent satire are the two main elements of the humour narrative. In this context, the period between 1956 and 1965 sees the development of Romanian film comedy, which advocates a type of humour consonant with the official discourse: the optimistic comedy, built around a central positive character, using a benevolent, kind satire to correct slight mistakes in these heroes. This article has sought to argue that the study of humour can help in the understanding of the history of communism in Romania. Also, through this research, I wanted to show that humour is an important political, social and cultural phenomenon. Far from being a simple 'harmless' phenomenon, humour has always been subject to multiple constraints: to have an ideological function, to be popular, to be educative, and to contain meaningful ideas for society.

This work is licensed under a Creative Commons Attribution-Non-commercial-Share Alike 4.0 International License. To view a copy of this license, visit https:/ / creativecommons.org/licenses/by-nc-sa/4.0/.

(C) School of Slavonic and Eastern European Studies, University College London, 2018. 
Ignat - The Discourse on Humour In the Romanian Press Between 1948-1965

\section{REFERENCES}

Alexandrescu, Sică, 'Un succes al literaturii noastre satirice' [A Triumph of our Satirical Literature], Contemporanul 18(395) (30 April 1954).

Alterescu, Simion, 'Două satire la adresa birocratismului' [Two Satires on bureaucratism], Contemporanul 109 (29 October 1948).

Alterescu, Simion, 'Dramaturgii nostri combat birocratismul' [Our Playwrights against bureaucratism] Contemporanul 125 (25 February 1949).

Bakhtin, Mikhail, Rabelais and his world (M.I.T. Press, Cambridge, 1968).

Barna, Ion, 'Vrem să râdem’ [We Want to Laugh] Contemporanul 9(751) (3 March 1961).

Beach, Christopher, Class, Language, and American Film Comedy (Cambridge University Press, Cambridge, 2004).

Bergson, Henri, Le rire. Essai sur la signification du comique [Laughter. An Essay on the meaning of the Comic] (Presse Universitaire de France, Paris, 1900).

Bilton, Alan, Silent Comedy Film and American Culture (Palgrave MacMillan, London, 2013).

Boiangiu, Alexandru, 'Cu Marincea e ceva' [There is Something about Marincea] Contemporanul 36(413) (3 September 1954).

Călin, Vera, 'Râsul care nu depreciază’ [Laughter is not denigrating] Contemporanul 15(549) (12 April 1957). 
Ignat - The Discourse on Humour In the Romanian Press Between 1948-1965

Cătănuș, Dan, Impactul raportului secret asupra conducerii PMR. Destalinizarea în România[The effects of Secret Speech on Romanian Workers Party. De-Stalinization in Romania] in, Lagărul comunist sub impactul destalinizării: 1956 [De-Stalinization in Eastern Bloc.1956] ed. Dan Cătănuș, Vasile Buga, (Bucuresti: Insititutul Național pentru studiul Totalitarismului, 2006).

Cătănuș, Dan, Tot mai departe de Moscova [Further away from Moscow] (București: Institutul Național pentru studiul Totalitarismului, 2011).

Coser, Rose, 'Some social functions of laughter: A study of humour in a hospital setting,' Human Relations 12.2 (1959).

Dale, Alan, Comedy Is A Man in Trouble. Slapstick in American Movies (University of Minnesota Press, Minneapolis, 2000).

Deletant, Dennis, Romania under the communist rule (The Center for Romanian Studies, Oxford, 1999).

Drăgan, Mircea, 'Directorul nostru' [Our Director] Contemporanul 14(444) (8 April 1955).

Drăgan, Mircea, 'Realizarea comicului în filmul Cu Marincea e ceva' [The use of comic devices in the movie There is Something about Marincea] Probleme de cinematografie 6 (June 1954).

Freud, Sigmund, Der Witz und seine Beqiehung zum Unbewnßten [Jokes and their relation to the Unconscious] (Deuticke, Leipzig, 1905).

Gheorghiu-Dej, Gheorghe, Articole și cuvântări [Articles and Speeches] (București: Editura de Stat pentru Literatură Politică, 1956).

Grigoriu, Cezar, 'Comedia cinematografică’ [Film Comedy], Contemporanul 4(902) (24 January 1964).

Grindon, Leger, Hollywood Romantic Comedy: Conventions, History and Controversies (Wiley-Blackwell, Oxford, 2011).

(c) School of Slavonic and Eastern European Studies, University College London, 2018. 
Ignat - The Discourse on Humour In the Romanian Press Between 1948-1965

Gurău, Radu, 'Pentru comedie' [For Comedy] Contemporanul 32(721) (5 August 1960).

Harvey, James, Romantic Comedy in Hollywood: from Lubitsch to Sturges (Da Capo Press, 1998).

Horodincă, Georgeta, 'Comicul minimalizează?' [Humour scoffing at the world] Contemporanul 13(547) (29 March 1957).

Horton, Andrew, Inside Soviet Film Satire: Laughter with a lash (Cambridge University Press, Cambridge, 1993).

Horton, Andrew, Joanna E. Rapf (eds.), A Companion to Film Comedy (Wiley-Blackwell, Oxford, 2013).

Hristea, Ion, 'Dramaturgia filmului muzical' [Musical Film Narrative] Contemporanul 49(895) (6 December 1963).

Iliadi, Alexandr, 'Scopul și mijloacele satirei' [The Purpose of Satire] Contemporanul 47(424) (19 November 1954).

Ionescu, Ghiță, Comunismul în România [Communism in Rumania] (București: Editura Litera, 1994).

Iosifescu, Silvian,'Unele probleme ale creației literare satirice' [Some problems regarding the satirical literature] Contemporanul 19 (8 May 1953).

Janko, Richard, Aristotle on Comedy. Towards a reconstruction of Poetics II (University of California Press, Los Angeles, 1984).

Karnick, Kristine, Henry Jenkins (ed.), Classical Hollywood Comedy (Routledge, New York, 1995).

King, Geoff, Film Comedy (Wallflower Press, London, 2002).

Kuipers, Giselinde, 'The sociology of humour,' in, Victor Raskin (ed.), The Primer of Humour Research, pp.365-402 (Mouton de Gruyter, Berlin/New York, 2008), p.368.

(C) School of Slavonic and Eastern European Studies, University College London, 2018. 
Ignat - The Discourse on Humour In the Romanian Press Between 1948-1965

Luca, Eugen, 'Reînvierea unui gen literar' [The Revival of a Genre] Contemporanul 38(363) (18 September 1953).

Luscalov, Petre, 'Despre unele probleme ale eroului pozitiv' [On some aspects of the positive character] Contemporanul 41(418) (8 October 1954).

Macovei, Simion, 'În legătură cu eroul pozitiv în comediile noastre cinematografice' [On the positive character of our film comedy] Probleme de cinematografice 7 (July 1955).

Macovei, Simion, 'Pe răspunderea mea' [On my responsibility] Film 5 (May 1956).

Malencov, G.M., Raportul de activitate al Comitetului Central al P.C.(b) al U.R.S.S. la Congresul al XIX-lea al partidului, [The annual report of the Central Comitee at the 19th Congress of the CPSU] (București: Editura pentru Literatură Politică, 1952).

Mast, Gerald, The Comic Mind: Comedy and the Movies (University Press of Chicago, Chicago, 1979).

Mesaroșiu, Titus, 'Mijloace de expresie în reportajul cinematografic satiric' [Means of expression in satirical film] Probleme de cinematografie 5 (May 1955), p. 46.

Mihăileanu, Ion, 'Un surîs în plină vară’ [A Midsummer's Smile] Contemporanul 13(911) (27 March 1964).

Modorcea, Grid, Dicționarul filmului românesc de ficțiune [The Dictionary of the Romanian Feature Film] (Bucuresti: Cartea Românească, 2004).

Mortimer, Claire, Romantic Comedy (Routledge, London, 2010).

Mulkay, Michael, On Humour: Its Nature and Place in Modern Society (Polity Press, Oxford, 1988). 
Ignat - The Discourse on Humour In the Romanian Press Between 1948-1965

Narti, Ana Maria, 'Comedia cinematografică - o nouă vârstă de aur?’ [A new golden age of the film comedy?] Contemporanul 40(990) (1 October 1965).

Narti, Ana Maria, 'Noua tinerețe a unor vechi comedii' [The heyday of the old comedy films] Contemporanul 13(859) (29 March 1963).

Petrescu, Cezar, 'Caragiale și marii clasici rusi' [Caragiale and the great Russian writers] Contemporanul 4 (25 January 1952).

Powel, Chris, George Paton (eds.), Humour in Society: Resistance and Control (MacMillan, Basingstoke, 1988).

Prokhorov, Aleksander, "Cinema of Attractions versus Narrative Cinema: Leonid Gaidai's Comedies and El'dar Riazanov's Satires of the 1960's',' Slavic Review 62.3 (2003).

Radcliffe-Brown, Alfred, 'On Joking Relationship,' Journal of the International African Institute 13.3 (1940).

Raicu, Lucian, 'Să continuăm marea tradiție a satirei noastre' [Following the great tradition of our satire] Contemporanul 16 (341) (17 April 1953).

Saul Austerlitz, Saul, Another Fine Mess. A History of American Film Comedy (Chicago Review Press, Chicago, 2010).

Schileriu, Eugen, 'Alo..ați greșit numărul' [Hello..Wrong Number] Contemporanul 51(637) (26 December 1958).

Șelmaru, Traian, 'Insemnări despre eroul comediei satirice' [On the hero of the satirical comedy] Contemporanul.36(934) (4 September 1964). 


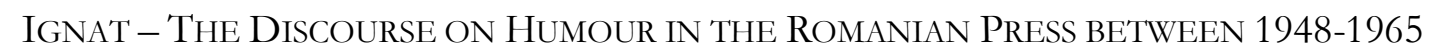

Silvestru, Valentin, 'Realism și comedie satirică’ [Realism and Satirical Comedy] Contemporanul 3(745) (20 January 1961).

Speier, Hans, 'Wit and politics. An essay on laughter and power,' American Journal of Sociology 103 (1998).

Taylor, Richard, "A "Cinema for the Millions": Soviet Socialist Realism and the Problem of Film Comedy,' Journal of Contemporary History 18.3 (1983).

Tolu, Mihai, 'Post-restant,' Contemporanul 18(812) (4 May 1962).

Zijderveld, Anton, Reality in a Looking-glass: Rationality through an Analysis of Traditional Folly (Routledge, London, 1982). 